\title{
The Strength of the Invisible: Reflections on Heraclitus
}

\author{
WILLIAM $W$. CLOHESY \\ Rochester Institute of Technology
}

Heraclitus seeks to inclicate the meaning and power active but invisible in the rich spectacle of the sensible world. In his effort of discovery and description he is one with the earlier poets, who sang tales of gods and godlike heroes; with the Ionian natural philosophers, who proposed a unity encompassing the patterns and processes all about them; and with subsequent philosophers who envision etermal Ideas and underlying essences. Yet Heraclitus stands apart both from the poets and from other philosophers through his acceptance, indeed appreciation, of an ever-changing, strife-filled experience. The onrush of experience is not to be tamed by stories dear to human imagination, not to be explained by a material first principle with subsequent processes, and not to be constrained within universal conceptual schemes. Rather, the events in turmoil flowing through our lives need to be freely met and examined in themselves if we are to glimpse a meaning and concord hidden there. If we approach experience preoccupied with our own purposes, we will overlook much that is there for us to find. Heraclitus admonishes. "Unless you expect the unexpected you will not find the unexpected, for it is undiscovered and unexplored."

Despite his openness to the variety of the sensible world, Heraclitus teaches that there is a unity to be glimpsed bounding the ceaseless change, a harmonious structure recognizable to human reason, expressible in words, but elusive to human senses: "all things are one" (Fr. 50 |118, XXXVI|).

Further, Heraclitus focuses his attention not only upon the sensible world surrounding human beings, the flow of rivers, the movements of the heavens, and other such events, but upon the place of human beings within these events, above all the activity of citizens within the walls of their city. In this he praises the excellence of humans of which the bards sing, but on the quite different ground of the place of human excellence within the cosmic whole. In so relating excellence to the city, he is one with the later philosophers; however, he does not suggest that one should turn away from mortal affairs to find the wisdom to deal with 
them. Order and meaning can be glimpsed in the city just as they can be anywhere. For humans, moreover. the activity of establishing and preserving a city makes possible a life in unison with the divine.

Heraclitus seeks to enunciate a philosophical insight about the world; in order to express his insight, he needs the skill of a poet as well as the vision of a philosopher. He must speak of what is invisible so that it will be apparent to one who sees, hears, and thinks. Like the Delphic oracle, who "neither declares nor conceals, but gives a sign" (Fr. 93 |18, XXXIIII), Heraclitus uses imagery and paradox to incite others tó follow the path of his thought indicated to them in the reverberating allusions of his words.

My purpose in this article is to present a unified reconstruction of Heraclitus's thought as we know it through the fragments. Toward this end I shall grapple with the purposeful obscurity of his language which enables him, through metaphor, to draw the reader's attention away from the visible spectacle he describes to the invisible which gives it coherence. My plan for this article has four parts. I will first present a discussion of the technique of metaphor which Heraclitus learned from his bardic predecessors. Alert to Heraclitus's use of metaphor, I.will then examine three crucial images in Heraclitus: (1) physis, the mysterious source of all that comes into being and disappears, which manifests itself in the ordered whole in flux of the kosmos; (2) logos, the human capacity to render into words events and structures of experience so that the intelligibility of the kosmos can be a common human project for articulation; and (3) nomos, the rule of law in a city through which humans act as a source of intelligible order within the city's walls as physis acts within the kosmos as a whole. My reconstruction will be. I trust, of value both for integrating the key themes of the Heralitean fragments into a comprehensive whole and for study of later currents in Greek thought.

\section{The Poets}

Heraclitus disclaims the bardic tradition, for the poets sing of things they do not know. The stories they tell are popular because of their facile significance for those who listen, just as the stories parents tell small children describe a world that makes sense in a nursery. The bardic myths depict the world as the work of humanlike gods whose ambitions and motives make them but men and women with powers and enjoyments written large. Heraclitus was familiar with Xenophanes (see Fr. 40 [6, XVIII]), slightly his elder, who ridiculed the myths for attending to all experience from a human point of view. Xenophanes argues, "But if cattle and horses or lions had hands, or were able to draw 
with their hands and do the works that men do, horses would draw the forms of the gods like horses and cattle like cattle, and they would make their bodies such as they each had themselves."

It is childish to expect that all of experience is like the experience familiar to us. Further, it is presuinptuous for us to expect to find our goods and purposes reflected throughout the world. "To God all things are beautiful, good, and right; men, by contrast, consider some right and others wrong" (Fr. 102 (106, LXVIII]). If the world has purposes, they need not be ours. The poets fail because they do not try to say truly how things are. They describe the obvious and praise the accepted, heedless of subtle distinctions which comprise the truth." Listening to the poets, one is encouraged to comprehend the world wholly in terms of oneself and one's desires. But we should grow up. "We should not listen like children to their parents" (Er. 74 [135, XIII]). Rather, we should seek to be present before experience as it presents itself for intelligent inspection to all who can see and think: "The waking have one world in common; sleepers have each a private world of his own" (Fr. 89 |15, VI I).

Foolish though their myths might be, the bards were the first to struggle to express the invisible power active within the sensible world. When someone quakes with fear, or fights rather than give ground before an enemy's onslaught, invisible feeling or strength of purpose is as present as the racing pulse or flashing sword. The emotion or commitment cannot be described as can sensible experiences such as a face or a forceful blow. The poets learned to indicate the invisible through comparisons, metaphors and similes, with sensible objects." An example should make clear the poetic technique.

In the Iliad Homer likens the Greeks' steadfastness in battle to a rocky cliff withstanding the sea:

\begin{abstract}
like some towering / huge sea-cliff that lies close along the grey salt water/ and stands up against the screaming winds and their sudden directions / and against the waves that grow to bigness and burst up against it./ So the Danaans stood steady against the Trojans, nor gave way.s
\end{abstract}

The rocky sea-cliff displays the quality of immobility which Homer uses to indicate the endurance of the Greeks. The richness of Homer's image allows a wealth of correlations to develop in the listener's imagination: the sea-cliff set upon by countless thrashing waves and screaming winds, the Greeks assaulted by unrelenting throngs of battle-crazed Trojans. Reflecting upon the scene Homer describes, the listener is drawn back to consider more closely the human scene. 
Although one might too quickly say that the rocks are "anthropomorphized" by comparing them to the Greeks, it is truly the humans who are "petromorphized," for their standing fast in the heat of battle has become palpable through the image of the rocks.

Persons come to recognize the invisible forces both within themselves and throughout their world by using the sensible world as a sort of mirror in which they see the likenesses of feelings, powers, patterns, and purposes which cannot be grasped in sensuous immediacy. These likenesses provide a representational means for sharing their insights with others, so that through discussion and common reflection the world beyond sensible experience becomes a determinate part of a common human reality.

Although philosophers such as Heraclitus abandoned the mythic and heroic world of which the poets sang, they retained the technique of metaphor and simile in order to indicate a reality beyond the sensible. Heraclitus, thereby, discusses experience and its order through reflection upon the bow and lyre, sleep and wakefulness, a river, and the volatile all-consuming fire. These images are intended to draw our attention beyond them to insights about the world which cannot be shown sensibly but only alluded to through images for thought.

\section{Physis}

For Heraclitus, as for all Greek thinkers, the primary experience to be faced is the ceaseless coming to be and passing away of a wealth of qualities, objects, and animals, as well as mortal humans. The wondrous display calls forth the question of its origin or source. The Milesian natural philosophers had asked after the source as a first principle, arche, whose transformations shape the sensible history of the world. Heraclitus follows these thinkers in acknowledging a source and naming it 'physis'. Derived from phyein (to grow, to sprout, to beget), 'physis' names the process of coming into the world as babies are born or plants sprout from the ground. 'Physis', then, indicates at once (1) the activity of springing forth into being, (2) the source from which all that appears enters into appearance, and (3) the rich, meaningful interlacing of all coming into being.'

A contrasting view of physis takes it to be the material of all things. John Burnet, for example, writes," . . . the name Iphysisl was given to the everlasting something of which the world was made. That is quite in accordance with the history of the word, so far as we can make it out. Its original meaning appears to be the 'stuff' of which anything is made, a meaning which easily passes into that of its make-up, its general character or constitution." I 
hope in the course of this article to offer a number of reasons for questioning so limited a definition of physis. On the grounds of the Greek language alone, however, one can argue that to speak of physis as the stuff of the world is far too constraining. Physis is a noun denoting an activity, phyein, just as praxis denotes the action prassein. Burnet loses the sense of activity, of the world as a process, of events as the constitution and dissolution of objects and their meanings. The Greeks were far too careful in the use of their tongue to indicate activity when they meant "stuff." Even the Milesians sought an arche, a beginning element out of which the process of the unfolding of the sensible world began.

As an activity, its source, and the emergent harmonious order, physis is invisible; we encounter only the particular manifestations which have come forth. Physis shows itself to us through its appearances, and beckons us to acknowledge it as the active source of all which comes into being. A hint or a sign of physis is all that we are given by the passing display. "Physis loves to hide," says Heraclitus (Er. 123117. $x \overline{] l}$. To say more, such as to personify physis, is an unwarranted play of imagination--"Let us not make arbitrary conjectures about the greatest matters" (Er. 47 (5, XI]). To deny physis because it does not show itself more directly is to ignore the full significance of all that does appear to us.

Further, physis should not be construed as a separate, other being, as a substance or hypokeimenon, which only takes on accidental sensible qualities or gives off appearances as semblances which it is not. The appearances of physis are instances of physis manifesting itself, the many ways by which the one shows its presence in activity.

The full manifestation of physis as a world Heraclitus terms 'kosmos', again adopting a Milesian word. Kosmos is not merely the product of physis such that physis stands apart flom it. Physis is the active source of all that comes into being. The kosmos is the realization and manifestation of this activity. Physis is inextricably linked to kosmos. Without the kosmos physis would not be a source of activity. Further, for the kosmos truly to reflect physis, it must be activity as well. We should think of the kosmos, then, as events and processes, not as a plenum of things. A river is not a thing so much as a pathway of flowing water. A lyre as an instrument is the possibility of making inusic. To say that something is, for Heraclitus, I suggest, is to say that something can happen. We can say of the kosmos, then, that it is physis articulate in action, but that physis as source is never exhausted in its cosmic ordering and display. Nor is the kosmos ever given as a whole which is complete, for it would then no longer be an activity. 
It is through attendance to these manifestations making up the kosmos that Heraclitus intends to approach physis in thought. Heraclitus is intent, then, on taking up exactly what is offered for thought in and through appearance. He writes, "My own method is to distinguish each thing according to physis lkata plysinl and to specify how it behaves; other men, on the contrary, are as forgetful and heedless in their waking moments of what is going on around and within them as they are during sleep" (Er. 1 [1, I]). Accepting each thing for what it is as it comes from physis, respecting its place within the cosmic display and parade of appearances, we should neither merely use it for our own purposes nor rip it from its context so as to peer at it in meaningless isolation.

The objects of appearance, to be sure, do not come into being or pass away in isolation. Qualities succeed one another, as dark the light; objects interact so that there is the alteration of each by the other or the destruction of one for the endurance of the other. Conflict, interplay, destruction, and endurance are everywhere and ceaseless. At times it is the change or strife that is most apparent, while the continuity of the opposing moments forms an invisible series culminating in a coherent, if transitory, whole. The succession of cold by warmth can, at times, be a sign as well as a shift: a sign that now is the time for planting. The seemingly permanent, by contrast, carries with it a real and effective change invisible but recognized by anyone who reads the signs. Heraclitus offers his most famous example, "One cannot step twice into the same river, for other (hetera kai hetera) waters are continually flowing on."10 The course the waters take has a seeming permanence to which we refer in naming the river. The one stepping in or wading across the river has a personal history, a permanence of character and continuity of experience, held together by a name as well. The continuity gives a familiarity which is unremarked. Yet the river banks and the human body are boundaries, within which there is a ceaseless flow of change and conflict which permit the apparent, named entities to be seen and recognized.11 For Heraclitus, then, both change and stability are at times apparent qualities of the world in which each gives signs hinting that the other is recognizably present although unseen.

The ceaseless and pervasive strife at work in the world does not reduce all simply to weary, pointless chaos. On the contrary, the discord and the struggle for supremacy we see all about us coalesce at times into harmonies or unities among the moments of discord and tension themselves. This is not a pattern imposed from outside on disparate elements, but a concord which comes into being precisely because the interacting elements align themselves through their strife into an ar- 
rangement with one another. Heraclitus writes, "People do not understand how that which is at variance with itself agrees with itself. There is a harmony in the bending back, as in the case of the bow and the lyre" (Er. 51 [117, LXXVIIIJ). In both examples, the bow and the lyre, the wood is spanned by a string. As the string is tightened, the two ends of the wooden frame are pulled so that they should bend toward each other. At the same time, however, the wooden frame resists the force of the string by pulling back so that the frame does not bend. The opposing forces withstand each other, and the instrument or the weapon lies ready but unmoving. The balance of forces constitutes a graceful whole offering the possibility of fruitful use. The opposition or tension is invisible, but it is most powerful and effective. Although the tension is invisible, it makes the visible structure meaningful. Heraclitus generalizes, "The invisible harmony is stronger than the visible" (Fr. 54 (116, LXXX)). ('Harmony' means not only musical attunement, but any kind of purposeful structure or connection.) Heraclitus gives examples of tensions within instruments of human design, and yet many do not comprehend their significance. Is it surprising, then, that strife and the resulting balance in the world at large pass unnoticed by so many?

It should be remembered that Heraclitus is not offering to detail a universal purpose or systematic order arising from the strife pervading experience. More humbly, he argues that harmonies are available within the complex experiences coming forth from physis to those who seek them. Not all are harmonies consonant with human purposes, which in part explains why they are often not noticed by the many caught up in their own affairs. An order or structure can be recognized and appreciated only if one approaches it from the right perspective. Heraclitus suggests, "Sea water is at once very pure and very foul; it is drinkable and healthful for fishes, but undrinkable and deadly for men" (Er. 61 |101, LXX]). It is easy for humans to recognize their advantage alone and thus to remain ignorant of real although alien coherence all about them. Although Heraclitus articulates no universal structure for the kosmos, the manifold of change and struggle has a single source and forms a unity in plurality in physis. Strife is necessary so that order can arise out of it. Points of coherence are culminations of processes which, having arisen, will pass away: "the many come from one and the one from many" (Fr. 10 1112, CXXIVI). What will always remain, however, is the activity of forming coherence, physis itself. There is no final organization bringing everlasting peace or fulfillment. Strife is constant, but, Heraclitus urges, there is a power of ordering active throughout the kosmos. 
Because individual formations, such as a river, are intelligible, Heraclitus infers that the whole kosmos is intelligible. He asserts, "Wisdom is one: knowing the plan by which to steer all things through all" (Fr. 41 (120, LIVI). As the source of an intelligible kosmos, physis surely deserves to be deemed divine. Yet it is a mystery, a power to be acknowledged, but not to be treated familiarly: "The one wisdom is alone willing and not willing to be called by the name of Zeus" (Fr. 32 1119, CXVIIII). The one wisdom (hen to sophon! is most accessible to human thought through personifying it as a god. Yet such a way of thinking should be recognized as problematic. Heraclitus indicates the problem by speaking of wisdom in the neuter gender only to ascribe the act of willing to it. Zeus, as ruler of the gods and of mortals, is alone the most fitting name for this wisdom, but it does not fit. For by naming this mysterious, wise physis, one pretends to have gained communication, familiarity, and even control, although this is not possible: The one wisdom, physis, is alone; it does not enter personally into human affairs as do the mythic gods. ${ }^{12}$ Further, physis is not an ageney, like a god, separate from the kosmos it realizes; it cannot intercede, for it is not a power apart. It is the power active throughout and within the kosmos.

Heracilitus does not intend to replace one myth with another or to offer idle speculations on the origin of the kosmos. In one elegant and enigmatic assertion, Heraclitus forecloses such aims: "The kosmos, the same for all, no god nor man has made, but it ever was and is and will be: fire everlasting, kindled in measures and in measures going out" (Fr. 30 [29, XXXVII]). The subtlety and controversy of this statement provide an inexhaustible subject for reflection and analysis. With no pretense at doing more than offering suggestions for reflection on Heraclitus's meaning, I shall make the following remarks:

(1) 'Kosmos' basically refers to any organized whole or arrangement, such as civil law, a deployment of troops, or a work of art. On this meaning every harmony coalescing from opposing forces is a kosmos. So, the entirety of these realizations of physis, the plurality throughout which there are ceaseless formations and dissolutions of unity, is also a kosmos, the kosmos.

(2) No principle or god external to physis and its kosmos is needed because the kosmos itself as a process is eternal--it always was and always will be. The power of physis to turn strife into harmony, to make opposition fruitful, displays itself in the activities which constitute the kosmos.

(3) Heraclitus's meaning in equating the kosmos and fire has caused debate at least since Aristotle took Heraclitus to identify fire as the arche or material 
cause of all else."3 Should Heraclitus be taken to mean literally or metaphorically that all things are fire?

Writers who take Heraclitus literally to mean that all things are forms of fire place him with the Milesian philosophers. From the few fragments concerning fire these writers have made ingenious reconstructions of a cosmology based upon fire. 14 Heraclitus is influenced by the Milesians to be sure; their view of the kosmos as internally intelligible is an essential ground for his thought. Heraclitus, however, is not concerned with a beginning and its unfolding. He explicitly denies that the fire of the kosinos is an arche by calling the kosmos eternal--without beginning. Further, while there are fragments suggesting a kosmos based on fire, there are others suggesting disdain for the wide-ranging emiprical investigations of the Milesians's and others (mockingly?) asserting prescientific views. ${ }^{16}$ Given such difficulties it is prudent to suspect that Heraclitus's claim that the kosmos is $f$ ire is as purposefully perplexing as so many other's of his statements. He uses sensible imagery to direct attention to what is not sensible: It is likely, then, that fire should be considered metaphorically.

(4) Matter in general can be ordered in a continuum with respect to density: solid, liquid, gas or vapor. Fire does not $f$ it into this continuum, for it is not a thing. Fire is darting, crackling, consuming activity. Moreover, fire is an activity which (a) shows itself to us by its own light; (b) works both constructively and destructively; and (c) makes other things and events, which do not show themselves, visible to us. These qualities of fire make it the most concentrated and comprehensive image available to Heraclitus for inciting reflection upon physis and the kosmos. As with his other metaphors, so with fire: We must seek the insight about the world which Heraclitus is pointing out to us through his image.

(a) Fire, as noted above, is an activity which shows itself to us. Whatever else fire does, it gives off light, making it visible. In order to do this, fire consumes and exhausts materials, transforming them to maintain and enhance itself. One cannot separate fire from the flame or glow which marks its presence. No more can one speak of physis without its kosmos. Physis is a self-generating activity which shows itself through the kosmos it brings forth and directs according to its own designs. For the kosmos is not simply a show of power, but of intelligence bringing disparate elements together in coherence and of organization lost to dispersion so that new order might come forth.

(b) Fire is a medium both for construction and for destruction. Through fire some things can be changed into other things; fire, for example, enables us to cook foods and to alloy metals. To work construc- 
tively, fire needs fuel, which it changes to ash and smoke, as it transforms raw materials into goods. Heraclitus likens fire to gold: some things (fuel) can be exchanged for it (fire), and it can be exchanged for other things (goods). 17 Constructively. fire is the power of coordinating disparate materials into a process which culminates in one desired product. Analogously, the processes of the kosmos bring a plurality together in strife to form a harmonious whole. Fire as a power of change can also destroy structured wholes. Houses can be burned down and food reduced to charred cinders. As fire flares up and abates, so significant structures come together, show themselves, and disappear. All things, we might say, are metaphorically combustible: They can be combined in such a way that they give off a flash of coherence. These flashes ensure an undying fire, for they burst forth again and again throughout the kosmos. even though particular flames are extinguished. Throughout the kosmos, similarly, the process of organization always accompanies that of dissolution: Harmonious wholes dissipate while new ones arise.

(c) Not only does fire show itself to us by means of the light it gives off, fire enables us to see and to study other things and events.which do not show themselves by their own light. As we concentrate upon the objects of study, we tend not to notice, but to take for granted, the light we use. Similarly, we recognize and appreciate particular harmonies within the kosmos without noticing the power of physis effective within them and pervasive of the activities throughout the kosmos. The light is there nonetheless, as is the power of physis. Heraclitus hopes to cure us of our inattendance.

As fire gives the light to see coherent structures within the kosmos. so our attention ignites a metaphorical light of comprehension in our minds. When we follow Heraclitus's example and seek to recognize the activities of the kosmos itself and to comprehend its particular structures, that which we study is reflected in our minds as truth. When we are overwhelmed by our private desires and interests, the light of intelligence is extinguished; we wander blindly like drunkards, stumbling about under the influence of inchoate passion."

(5) Having indicated the metaphorical force of fire in Heraclitus's thought, the question arises again whether identifying the kosmos with fire has a significance beyond the metaphorical. Taking fire to be a self-manifesting activity, fire is poorly suited for use as a material principle. Prof. Charles $H$. Kahn writes, "But [fire] is a most unlikely choice for a starting point in a literal account of the development of the world in material terms, since it is not itself a kind of matter, not a body at all, but a process of 
transition from one state to another, a symbol of 1 ife and death at once, the very element of paradox."19 To separate fire off as the active force in the kosmos is problematic: The kosmos is itself activity, not matter formed and arrayed by an external power or by some favored part. Also, if fire were literally the arche and source of order, how could it be extinguished, as it so frequently is?

To say that the kosmos is everliving fire, I propose, is to use synechdoche: the most illustrative, provocative part of the kosmos is made to stand for the whole. For Heraclitus fire is of metaphorical importance because through it we grasp truths about the world which are not sensibly available. Fire differs from other images--the river, the salt sea, and the lyre--in its fecundity for reflection. It draws us to think of the activity of plyysis and its kosmos in a splendidly concise way. Fire's power as a metaphor is such that it alone does the work of many other images together.

Heraclitus's interest is not directed primarily at sensible experience; he intends to make a statement about the world as such, a statement rooted in but transcending sensible experience. Although he hasn't the word, Heraclitus uses fire metaphorically in order to speak with metaphysical significance. We can say that Heraclitus tries to move from the world as it appears to humans, kat' anthropon, to the world as it really is with respect to its origin and intelligibility, kata physin. Yet the perplexity of his images, fire above all, stands witness to the impossibility of achieving a knowledge of reality as it is kata physin. Although later philosophers will seek such knowledge of what is as it really is, Heraclitus presumes far less. He claims only to recognize the mysterious oneness of all in harmony and strife. Physis is no more to be enclosed by human thought than fire is to be grasped by human hands. We should attend to physis in its manifestations while respecting its ineluctable mystery for us. We always approach the world as it is for humans; but as humans we can acknowledge, respect, though never master physis. ${ }^{20}$

\section{I . Logos}

Physis, as the source of the variety and the intelligibility of all experience, is a mystery to be acknowledged. Awesome and remote, yet present in every instance of struggle and order, physis truly deserves the name 'divine'. The many, it is true, do not apprehend this source of order. They grasp only what is of peculiar interest to themselves. Their opinions and descriptions of their world express a private, selfcentered acumen lidia phronesisl (Fr. 2 12, IIIJ). Drawing together only portions and aspects of experi- 
ence surrounding them, the self-interested make mere opinions for themselves as incomprehensible to others as a dream. Heraclitus writes, "Most men do not think things in the way they encounter them, nor do they recognize what they experience, but believe things to be as they seem to be to themselves leoutoisin de dokeousin"l (Fr. 17 157, IVI). Their view is not of the objects themselves, but only of the objects with respect to themselves. They do not truly attend to the appearance of the object, but only to a partial view, rooted in self-interest, which might have no support in
the object as it appears itself.

It should be noted that the being of the object and its appearance are one for Heraclitus, whereas a distinction exists between the object as it truly is (and appears) and as it seems to me |dokei moil. This distinction foreshadows that of Paimenides, for whom there is a Way of Opinion (doxa) founded upon sensible experience and the Way of Truth guided by reason. The former inevitably leads to confusion because it concerns the changeable world of Becoming; the latter gives truth because it leads toward timeless Being. Heraclitus differs from Parmenides in that he finds fault with human responses to sensible experience, not with experience itself.' The manifestations of physis are adequate for a knowledge of the kosmos. Confusion and semblance are distortions humans bring upon themselves by failing to attend to what is present before them.22 Humans are not bound to the ignorance of foolish tales and to the chaos of a world confusedly perceived by one distracted. For they can concentrate not only upon themselves but upon the appearance of things and upon the invisible structures active within the complex of appearances.

Physis itself fashions an order which brings together the volatile, opposing moments of experience as the kosmos available for human comprehension. When humans attend to the concord which physis itself hides within the apparent discord of experience, they gather together their scattered experiences in keeping with the unity they recognize to be there. Humans can render an account of this unity, a logos, for one another. Logos, a most subtle and rich word, means word or speech, and, hence, a narrative or an account. As a display of words providing an intelligent explanation or reason regarding some event, logos comes to mean reason or the power of rational thought and comprehension. For Heraclitus physis acts within its kosmos with an inherent intelligence. Humans are capable of grasping and possessing the cosmic order through the power of logos: A structure linking events in experience, once recognized, can be presented in words; cosmic intelligibility is thereby reflected in human reason. As expression and representation, the logos is inherently communicative. The logos brings humans 
together in a shared comprehension of the intelligibility of physis.

True communication with another requires that the speaker so present his experience and its meaning that the listener is drawn to notice the same (or similar) events and comnections and to organize them toward an agreement with the speaker. Sharing the logos achieved by intelligent inspection, human witnesses to pluysis hold in common (xynoi) the findings of their senses sought with intelligence (xyn noi). The logos, which they articulate and share, is not their own creation; it is the expression of the structured unity which physis itself presents as the invisible harmony connecting all coming forth into being. Because the logos expresses a harmony within the kosmos itself, the agreement of all who remark it is the criterion of the truth of their discourse. The truth does not vary from speaker to speaker; it is the same for all. When one speaks the truth, then, one speaks for all and to all. Heraclitus admonishes. "Listening not to me but to the Logos, it is wise to agree |homolegeinl that all things are one" (Fr. 50 (118, XXXVIj). Inteliligibility, that is, is present in the kosmos, available for articulation as a logos. The human logos, then, binds humans together as communicative beings; and it binds them to the mysterious, divine physis, the source of the intelligibility expressed in the logos, as in all else.

\section{Nomos}

Heraclitus is philosophically concerned not only to account for the intelligibility of the kosmos to human beings, but also to make human beings intelligible within the kosmos. That is, the logos particular to human beings should be articulated. Humans are, above all else, animals possessing logos. Logos enables humans to deliberate on the kosmos and their situation within it; to persuade others of the truth in their comprehension of things; and to take prudent action in accordance with their thoughtful arguments. The capacity of logos, then, gives a twofold power: thought and thoughtful action. (If one takes the kosmos to be activity, as I proposed above, then humans should ultimately be intelligible in terms of the actions proper for them.)

Human beings can prosper only by acting together: this they can do because through their logos they can persuade others to join them in deliberate and concerted action. Although in human association conflicts and discord ever threaten to turn one against another in violence and hubris or arrogant self-assertion, a community can be preserved and its members offered a full life only through agreements: a body of law (nomos) establishing an intelligible order within the 
association by giving directions for action and limitations for the constraint of private interests.

For the Greeks all human activity beyond fundamental subsistance takes place within a city. Only in a city can people act together, with sufficient numbers and versatility, to live a good life in which they are challenged always to excel. According to traditional beliefs, excellence before others alone can give one hope for immortality. Humans are set off from all else as mortals. The gods live forever; animals are immortal in their species; but humans live as individuals, and so they can die away into futile oblivion. Only through the fame of noble words and deeds, remembered in stories or songs, can individuals be kept from disappearing. ${ }^{2}$ Heraclitus overturns this view of human mortality: Not only humans, but all things are mortal--save the directive intelligence of physis and the activity of the kosmos. All comes forth into being only to suffer change and disappear: "Immortals are mortal, mortals immortal, living the other's death, dead in the other's life" (Er. 62 [66, XCII]).

It is little comfort that all things, not only humans, are destined to pass away. Nevertheless, Heraclitus does not affirm or universalize the futility of mortals' words and deeds. For Heraclitus the significance of anything does not depend upon its permanence or impermanence, but upon its activity within the kosmos. For it is activity, not existence as such, which is crucial in Heraclitus's understanding of the harmony in strife of the kosmos. The activities proper to humans--thought and prudent action--link them with the intelligence of physis and give them an unique and estimable place within the kosmos.

Within a city humans create an intelligible order, a common good, which transcends their private interest's and their own brief lifetimes. Heraclitus echoes the Greek respect for public life, "The best of men choose one thing in preference to all else, immortal glory in preference to mortal goods; whereas the masses simply glut themselves like cattle" (Er. 29 (85, xCVIIJ). These are the best of men for through them intelligence shines in human affairs and a fruitful harmony of intention and deed overcomes the rancor and shortsightedness of self-interest.

Within a city thought and argument can mature, and opportunity for public excellence on behalf of the city abounds. The best live not simply for wealth and pleasure, but for excellence in word and deed by which they direct and protect their city. Among themselves, the citizens decide cases by means of laws rooted in their common wisdom concerning actions and ends proper for their city. Insofar as these laws are products of wisdom, they express the truth achieved by the citizens in argument. The laws are the common view, purified of private interest, asserted by all as one. Heraclitus 
states, "It is law to obey the counsel of one" (Fr. 33 [83, LXVI])--be that one a sage, a council, or the citizenry at large speaking the truth in unison. These laws establish an invisible harmony providing a propitious way of life and keeping the conflicts and transactions of all within commonly accepted bounds. The city, then, is a place of intelligible structure expressible as law, nomos, just as the entire world of appearances is held in harmony expressible as a logos. The kosmos, the bounded harmony of the city, reflects the larger kosmos of physis itself. Heraclitus writes, "Men should speak with rational awareness and thereby hold on strongly to that which is shared in common--as a city holds on to its laws, and even more so. For all human laws are nourished by the one divine law, which prevails as far as it wishes, suffices for all things, and yet is something more than they" (Er. 114 181, $\mathrm{XXX}$ (). As physis stands as the source of the kosmos intelligible to humans through their logos, so the citizens stand as a source of order for the city organized according to the laws the citizens articulate in common. That is, the citizenry as a source of intelligent order within the city form a microcosm of physis and the kosmos itself.

Although the city and the fame of the citizens is no more permanent that anything else, Heraclitus offers a view of humans which gives them a truly cosmic significance: initiators of harmony in the world of human affairs. Professor Werner Jaeger succinctly describes this view of humankind:

For Heraclitus, man is part of the cosmos, and as such he is subject to the laws of the cosmos in the same way as all its other parts. But since, by virtue of his own intellect, he harbours within himself the eternal law of the life of the universe, he can share the highest wisdom, from whose counsel springs the divine law. The freedom of the Greek lies in the fact that he subordinates himself, as one part, to the whole which is the city-state, and to its law. ${ }^{24}$

Heraclitus has attempted to face unblinking the ceaseless strife, the unabating change which confronts us, while yet recognizing the underlying unity of all that changes through the activity of harmonizing physis. Without turning away from the world of appearance, he has tried to show an intelligent power at work throughout all things, holding them back from falling into chaos, which is itself invisible although recognizable in its efforts. Heraclitus's language, so rich in metaphors, has made the sensible world an instrument enabling him to instigate reflection upon the nonsensible powers effective upon sensible experience. obscure, paradoxical to be sure, Heraclitus's words ex- 
press a comprehension of the world as thoroughgoing change in a coherent unity, a world, moreover, in which there is a significant and honorable place for humans as themselves a source of intelligibility in the world of human affairs.

\section{NOTES}

Earlier versions of this article were presented as papers at Shimer College in Waukegan. Illinois; and at the State University of New York at Geneseo. I wish to thank Prof. Dane Gordon for helpful discussions of the issues in this article.

${ }^{1}$ Fragment 18 (19, VII). All Heraclitean fragments cited here are based upon the two following references, although I have made a number of significant changes in the translation: Philip Wheelwright, Heraclitus (New York: Atheneum; 1959, 1964) and Charles H. Kahn, The Art and Thought of Heraclitus: An Edition of the Fragments with Translation and commentary (Cambridge: Cambridge University Press, 1979). The fragment numbers are those of Diels, followed in brackets by Wheelwright's and Kahn's numbers, respectively.

${ }^{2}$ G. S. Kirk and J. E. Raven, The Presocratic Philosophers: A Crtical History with a Selection of Texts, corrected ed. (Canbridge: The University Press, 1964), 172. 169.

'See Fr. 57 (114, XIX): "The teacher of most is Hesiod. It is him they know as knowing most, who did not recognize day and night: they are one."

"See Bruno Snell. The Discovery of the Mind: The Greek Origins of European Thought, trans. T. G. Rosenmeyer (New York and Evanston: Harper and Row, Publishers, Harper Torchbooks, 1960), 191-205. Also see Hannah Arendt, The Life of the Mind, vol. 1: Thinking; vol 2: Willing, 2 vols. (New York and London: Harcourt Brace Jovanovich, 1978), 1: 98-112. A discussion of current work on metaphor is to be found in Fred Dahlmayr, Language and Politics: Why Does Language Matter to Political Philosophy? (Notre Dame and London: University of Notre Dame Press, 1984), Chapter six: "The Rule of Metaphor," 148-73.

${ }^{5}$ The Iliad of Homer, trans, with an Introduction by Richard Lattimore (Chicago and London: The University of Chicago Press, 1951, 1971), 15. 618-622, 325-26. 
See Snell, 200-01. Prof. Dihlmayr suggests that "one might say that metaphorical language involves the ability of the poet or speaker to transfer himself into alien terrain, or to move back and forth between usages and contexts, in an effort to discover (manifest or latent) resemblances and distinctions," 151 .

'I follow Martin Heidegger in this derivation of physis. See his An Introduction to Metaphysics, trans. Ralph Manheim (Garden City, New York: Doubleday \& Co., Anchor Books, 1961), 11-14. Heidegger expands, "Physis as emergence can be observed everywhere, e.g. in celestial phenomena (the rising of the sun), in the rolling of the sea, in the growth of plants, in the coming forth of man and animal from the womb. But physis, the realm of that which arises, is not synonymous with these phenomena, which today we regard as part of 'nature'. This opening up and inward-juttingbeyond-itself (in-sich-aus-sich-hinausstehen) must not be taken as a process among other processes that we observe in the realm of the essent. Physis is being itself, by virtue of which essents become and remain observable." 12 .

- John Burnet, Early Greek Philosophy 3rd ed. (Cleveland and New York: The World Publishing Company, Meridian Books, 1964), 10-11.

'See the discussaion of physis in Werner Jaeger, Paideia: The Ideals of Greek Culture 3 vols.. trans. Gilbert Highet, 2 nd ed. (New York: Oxford University Press, 1945), 1: 155ff. variants.

${ }^{10}$ Frs. 12 and $91(21, \mathrm{~L}$ and $\mathrm{LI})$, reconstructed from

"See Snel1, 219; Kahn, 168.

12 "Alone" (mounon) I take to be purposefully ambiguous in the cited fragment. The word refers to wisdom as one and apart. It also indicates that only wisdom is willing etc.

${ }^{13}$ See Metaphysics. A, 3.984'5ff.

"See Burnet, 145-52; Kirk and Raven, 199-207; Wheelright, 37-57.

is"Much learning (polymathie) does not teach comprehension (noon) . . . " Fr. 40 (6, XVIII). Fr. 3 (37, xLVIi). the sun is the size of a human foot." 
"Fr. 90 (28, XL). See Harold Cherniss, "The Characteristics and Effects of Presocratic Philosophy," Journal of the History of Ideas 12 (1951).

CVI): 118 (46, 36 CIX). $(49$, CII): 77 (47, CVIII); 117 (48,

'Kahn, 138.

$2{ }^{\circ} \mathrm{Heidegger} \mathrm{s}$ interest in the Presocratics stems in part from their awareness that their philosophical reflections--their metaphysical concern for the beingness of being--can not seek to be absolute or selfcontained truth. Heidegger states. "Metaphysics moves everywhere in the realm of the truth of Being, which truth remains the unknown and unfathomable ground." Martin Heidegger, "Postscript" to "What is Metaphysics?" in Walter Kaufmann, ed. Existentialism: Erom Dosteovsky to Sartre (New York: New American Library, 1975), 258 . 88.

${ }^{2}$ See Snell, 147ff; Jaeger, 1: 175-180.

${ }^{22}$ See Heidegger, Introduction to Metaphysics, 84-

${ }^{2}$ The activity of immortalizing through remembrance was the responsibility of the poets in earlier times. The responsibility was taken over by the citizenry with the rise of the polis. Hannah Arendt discusses the activity of immortalizing in Between Past and Future: Eight Exercises in Political Thougl t enlarged ed. (Hammondsworth, Middlesex, England: Penguin Books,
1968 ), 63-75. She writes, "For Greeks and Romans alike, all differences not withstanding, the foundation of a body politic was brought about by man's need to overcome the mortality of human life and the futility of human deeds. Outside the body politic, man's life was not only and not even primarily insecure, i.e.. exposed to the violence of others; it was without meaning and dignity because under no circumstances could it leave any traces behind it." 71 .

$$
\text { 24Jaeger, 1: } 183 \text {. }
$$

